\title{
Differences in employment outcomes for college town stayers and leavers
}

\author{
John V Winters
}

Correspondence:

john.winters@uc.edu

Department of Economics,

University of Cincinnati and IZA, PO

Box 210371, Cincinnati, $\mathrm{OH}$

45221-0371, USA

\section{里

\begin{abstract}
New college graduates must choose whether to stay in the geographic area where they completed their degree or move to a new location to begin their careers. This paper classifies 41 U.S. metropolitan areas as "college towns" and investigates differences in employment outcomes between college graduates who stay in the college town where they obtained their degree and college graduates who leave after completing their degree. We find that college town stayers experience less favorable employment outcomes along multiple dimensions. On average, stayers earn lower annual and hourly wages and work in less educated occupations.
\end{abstract}

JEL codes: J61, R23

Keywords: Migration, Human capital, Higher education, College towns, Wages

\section{Introduction}

Investments in higher education have important benefits for individuals because human capital increases productivity, wages, and employment prospects (Psacharopoulos and Patrinos 2004) ${ }^{1}$. However, individual employment outcomes and benefits of education are inherently tied to location decisions. After completing their education, individuals have to decide where to begin their careers. Many college graduates will choose to begin their careers in different geographic areas than where they attended college, but some will remain in the same area as where they attended college (Huffman and Quigley 2002; Groen 2004; Oosterbeek and Webbink 2011). There are both benefits and costs in deciding whether to migrate and relative employment prospects likely play an important role.

Migration decisions are often viewed as human capital investments (Sjaastad 1962). In this framework individuals maximize their own expected utility and choose to live in the location that offers the highest expected utility. Thus, upon completing her degree, a college graduate will move to a new area if it gives her greater expected utility than the place where she earned her degree. The expected utility that an area offers will depend on a number of factors including wages and employment opportunities, the local cost of living, consumer amenities and quality of life, and the tastes and preferences of the individual making the migration decision (Clark and Hunter 1992; Franklin 2003). Chen and Rosenthal (2008) suggest that young college graduates are often most strongly attracted to large metropolitan areas with high wages and a strong labor market. Whisler et al. (2008) argue that cultural and recreational amenities also

(c) 2012 Winters; licensee Springer. This is an Open Access article distributed under the terms of the Creative Commons Attribution License (http://creativecommons.org/licenses/by/2.0), which permits unrestricted use, distribution, and reproduction in any medium, provided the original work is properly cited. 
play an important role in college graduate migration decisions. Furthermore, Berry and Glaeser (2005) and Waldorf (2009) suggest that educated individuals are attracted to areas that already have large numbers of educated people.

While some areas are certainly better than others at attracting and retaining recent college graduates, the optimal location will not be the same for all individuals. Individuals have different skill sets and different preferences for various locations. Furthermore, some graduates may develop human capital that is specific to the location where they earned their college degree (DaVanzo 1983; Krupka 2009; Winters 2011). For example, they may develop networks with professors and local employers that enhance their employment prospects in the area. Alternatively, recent graduates may have built strong friendships and developed a taste for local amenities that help tie them to the area where they attended college. These preferences for the place where they attended college may even incline some recent graduates to accept lower paying jobs to stay in the area that they have grown to love.

To date there has been very little research examining how employment outcomes for recent graduates are affected by staying in the area where they attended college. Previous researchers have examined the effects of migration on income and employment for various groups (e.g., Axelsson and Westerlund 1998; Yankow 2003; Boheim and Taylor 2007; Anil, Sjoquist, and Wallace 2010; Blackburn 2010a,b), but have not explicitly examined the effects of staying in a college town for recent graduates. Many recent college graduates might be better able to find gainful employment by relocating to a different labor market and of course many graduates do leave the area where they completed their education. Recent graduates who stay in the area where they earned their degree may pay a price for doing so, and this price is likely to be especially large in smaller labor markets that produce large numbers of college graduates, i.e., "college towns."

This paper seeks to fill an important gap in the research literature by investigating differences in employment outcomes between recent college graduates who stay in the college town where they obtained their degree and those who leave after completing their degree. Using decennial census data, we classify 41 U.S. metropolitan areas as college towns and examine differences in the probability of employment, annual wage income, hourly wages, annual hours worked, and a measure of the education level of a worker's occupation. The results suggest that, on average, college town stayers earn lower annual and hourly wages and work in less educated occupations. Thus, it appears that college town stayers generally experience worse employment outcomes than those who leave. These results continue to hold when we employ a difference in differences approach that treats recent graduates from large metropolitan areas as a control group and when we control for differences in the cost of living across labor markets.

\section{Empirical approach and data}

This paper examines wage and employment differences between recent college graduates who stay in the college town where they earned their degree and those who leave a college town after their education is complete. We focus on recent college graduates who earned their degrees in relatively small college towns because it is these graduates who are likely to have the greatest difficulty finding a good job in the area 
where they completed their degree. Large metropolitan areas like New York and Los Angeles have thicker labor markets and generally offer better employment prospects for recent graduates and are better able to retain recent college graduates (Whisler et al. 2008). This paper uses microdata from the 2000 Census available from the IPUMS (Ruggles et al. 2008) to classify 41 U.S. metropolitan areas as college towns. We define a metropolitan area as a college town based on the percentage of adults in the area who are enrolled in college. More specifically, an area is considered a college town if the share of the population age 18 and older enrolled in college is more than one standard deviation greater than the mean across all metropolitan areas. For the year 2000, the mean share of adults enrolled in college across metropolitan areas was 0.092, and the standard deviation across metropolitan areas was 0.050 . Thus an area is considered a college town if its share enrolled in college exceeds 0.142 . The 41 metropolitan areas meeting this criterion and included in this study are listed in Table 1.

Admittedly, this definition of college towns is a fairly restrictive one, and a case could be made that many areas not included should be rightfully considered as college towns. The present definition is intended to limit the analysis to areas where colleges and universities have a relatively large influence. Furthermore, the 41 areas meeting this criterion are also relatively small metropolitan areas having a mean population of 203,919. Again, it is these smaller areas in which recent graduates may suffer the most from staying in the area where they went to college. Ideally, we might also like to include non-metropolitan college towns, but unfortunately the Census public use microdata do not allow separate identification of geographic areas with populations less

Table 1 The 41 "college town" metropolitan areas included in the study

\begin{tabular}{ll}
\hline Albany-Corvallis-Lebanon, OR CSA & Kalamazoo-Portage, MI CBSA \\
\hline Ames-Boone, IA CSA & La Crosse, WI-MN CBSA \\
Athens-Clarke County, GA CBSA & Lafayette-Frankfort, IN CSA \\
Bellingham, WA CBSA & Lansing-East Lansing-Owosso, MI CSA \\
Blacksburg-Christiansburg-Radford, VA CBSA & Las Cruces, NM CBSA \\
Bloomington, IN CBSA & Lawrence, KS CBSA \\
Bloomington-Normal, IL CBSA & Lewiston, ID-WA CBSA \\
Champaign-Urbana, IL CBSA & Lincoln, NE CBSA \\
Charlottesville, VA CBSA & Logan, UT-ID CBSA \\
Cheyenne, WY CBSA & Lubbock-Levelland, TX CSA \\
Chico, CA CBSA & Madison-Baraboo, WI CSA \\
College Station-Bryan, TX CBSA & Morgantown, WV CBSA \\
Columbia, MO CBSA & Muncie, IN CBSA \\
Columbus-Auburn-Opelika, GA-AL CSA & Provo-Orem, UT CBSA \\
Flagstaff, AZ CBSA & San Luis Obispo-Paso Robles, CA CBSA \\
Gainesville, FL CBSA & Santa Barbara-Santa Maria-Goleta, CA CBSA \\
Grand Forks, ND-MN CBSA & State College, PA CBSA \\
Greenville, NC CBSA & Tallahassee, FL CBSA \\
Hattiesburg, MS CBSA & Tuscaloosa, AL CBSA \\
lowa City, IA CBSA & Waco, TX CBSA \\
Ithaca-Cortland, NY CSA & \\
\hline Ne: Metropotan areas a cassfied as "college & \\
\hline
\end{tabular}

Note: Metropolitan areas are classified as "college towns" if the share of the adult population (age 18 and older) enrolled in college is more than one standard deviation greater than the mean across all metropolitan areas. 
than 100,000. Consequently, the lowest level of identifiable geography, the PUMA, lumps very small areas together with other nearby areas that often span large land masses. This makes it harder to identify whether recent college graduates remain in non-metropolitan college towns because they might still be in the same PUMA but have moved to a new location a considerable distance from where they attended college. These geographic identification problems also affect a few of the metropolitan areas included in this study, though to a lesser extent than would be true for non-metropolitan areas.

After defining the 41 college town metropolitan areas examined in this study, we next wish to consider differences in employment outcomes between recent graduates who stay in these college towns and those who leave after completing their degree. We define recent college graduates as persons between the ages of 23 and 27 with at least a four-year college degree. We do not observe when an individual completed her degree, so our definition of recent is based on age. College graduates ages 23-27 at the time of the census were ages 18-22 five years before the census and were likely to have been enrolled in college but not yet have earned a bachelor's degree. The main results presented below are qualitatively robust to altering the age range to include persons ages 28 and 29 at the time of the census or exclude persons age 23 at the time of the census. Our initial analysis also restricts the sample to recent college graduates who resided in one of the 41 college towns five years prior to the census. Unfortunately, there may be some misreporting of previous residence for recent college graduates. Some recent graduates living in a college town five years prior may instead report their residence five years ago as their parents' residence. It is unclear how much or in which direction the resulting sampling and measurement error would affect the results.

The sample also excludes two groups of recent graduates. First, we exclude persons who are still enrolled in higher education in 2000. Since these people are still in school it does not make sense to compare their employment outcomes to those who have completed their schooling. We also exclude all persons born outside the U.S. since many of these only come to the U.S. for an education and leave after completing their degree. As a practical matter, the results below are qualitatively robust to including recent college graduates who are currently enrolled and foreign born graduates who are still in the U.S. in 2000, but the results presented do not include these groups of recent graduates. After restricting the sample along these dimensions we are left with 11,237 individuals.

We next define the binary variable, Stayer, which is equal to one if the recent graduate is still in the college town where she resided five years prior and zero otherwise. We then use linear regression to estimate differences between stayers and leavers for several employment outcomes controlling for differences in individual characteristics, $X$ i.e., we estimate regressions of the following form:

$$
Y=\theta \times \text { Stayer }+X \beta+\varepsilon
$$

The individual characteristics include separate dummy variables for the highest degree earned, age, whether the individual is female, Black, Hispanic, Asian, Other Nonwhite, married, or has children. One unfortunate limitation of the current paper is that there may be unobservable differences between stayers and leavers that also separately affect employment outcomes ${ }^{2}$. For example, leavers may be more ambitious and 
career driven than stayers. If drive and ambition also improve employment prospects, then failing to observe these will induce a negative correlation between employment outcomes and staying. Several previous studies have attempted to account for whether migrants are generally a self-selected group (e.g., Axelsson and Westerlund 1998; Yankow 2003; Boheim and Taylor 2007; Blackburn 2010). This usually involves trying to identify a variable that affects the probability of migration but does not separately affect employment outcomes such as proximity to family or housing tenure in the previous period. The census data used in this study do not offer information on either of these and we are thus unable to examine whether migration is endogenous for recent college graduates who earned their degree in a college town ${ }^{3}$. Instead, we examine the sensitivity of the results to employing a difference in differences (DD) technique that treats recent graduates from large metropolitan areas as a control group. More details are discussed later 4.

This paper considers five employment outcomes: 1) whether an individual is employed at the time of the census, 2) the log of annual wage income earned in the previous year, 3) the log average hourly wage in the previous year computed as annual wages divided by the number of hours worked in the previous year, 4) the log of hours worked in the previous year, and 5) the percentage of workers in the same occupation with a bachelor's degree or higher for employed recent graduates. This fifth outcome is intended to capture whether stayers are more likely to take jobs for which they are overeducated. The hypothesis of this paper is that college town stayers may experience worse employment outcomes than those who leave along a number of dimensions. Summary statistics for the dependent and independent variables for the full sample are reported in Table 2. A few things are worth mentioning. First, 92.3 percent of the sample is employed, reflecting the high rates of labor force participation and low rates of unemployment for young college graduates as well as the relatively strong labor market in 2000. Second, only 19.4 percent of recent graduates who lived in a college town five years prior are still in the college town where they completed their degree. The large majority, therefore, have either moved back to a previous location or moved on to a new location.

Table 3 presents the mean values of the dependent and independent variables separately for college town stayers and leavers and also reports the differences in the means and whether the differences are statistically significantly different from zero. This provides a first look at a number of differences between those who stay in a college town after completing a degree and those who leave. According to these raw differences, stayers perform significantly worse than leavers in all five of the employment outcomes that we study. Stayers have lower employment rates, earn lower annual and hourly wages, work fewer annual hours, and work in less educated occupations. However, the table also shows that there are important differences between stayers and leavers in individual characteristics. Stayers are significantly less likely to hold a master's or professional degree, and there are some differences in age between the two groups. Females are significantly more likely than males to stay in the college town where they completed their degree. Blacks are significantly more likely to stay than Whites, but Asians are significantly less likely to stay than Whites. Stayers are also significantly more likely to be married and more likely to have children. Being married and having children, therefore, appear to increase the costs of leaving and tie recent graduates to 
Table 2 Summary statistics

\begin{tabular}{lllll}
\hline Variable & Mean & Std. Dev. & Min & Max \\
\hline Employed & 0.923 & 0.267 & 0 & 1 \\
Log Annual Wage & 10.108 & 0.760 & 2.303 & 12.757 \\
Log Hourly Wage & 2.622 & 0.556 & -3.219 & 7.058 \\
Log Annual Hours & 7.487 & 0.558 & 2.079 & 8.546 \\
\% of Occupation with Bachelor's or Higher & 0.504 & 0.278 & 0.014 & 1 \\
Stayer & 0.194 & 0.396 & 0 & 1 \\
Master's Degree & 0.099 & 0.299 & 0 & 1 \\
Professional Degree & 0.032 & 0.177 & 0 & 1 \\
Doctoral Degree & 0.004 & 0.064 & 0 & 1 \\
Age 24 & 0.176 & 0.381 & 0 & 1 \\
Age 25 & 0.236 & 0.425 & 0 & 1 \\
Age 26 & 0.246 & 0.430 & 0 & 1 \\
Age 27 & 0.237 & 0.425 & 0 & 1 \\
Female & 0.553 & 0.497 & 0 & 1 \\
Black & 0.042 & 0.201 & 0 & 1 \\
Asian & 0.015 & 0.123 & 0 & 1 \\
Hispanic & 0.031 & 0.173 & 0 & 1 \\
Other Nonwhite & 0.013 & 0.114 & 0 & 1 \\
Married & 0.395 & 0.489 & 0 & 1 \\
Has Children & 0.141 & 0.348 & 0 & 1 \\
\hline Nes: The sample & 0.45 & 0 \\
\end{tabular}

Notes: The sample includes 11,237 individuals who resided in one of 41 college towns in 1995, who were no longer in school and had earned at least a bachelor's degree by 2000 , were between the ages of 23 and 27 in 2000, and were born in the U.S.

the area where they completed their degree. Because of these significant differences in individual characteristics, we cannot accurately assess the effect of staying on employment outcomes simply by taking differences in means. Instead, we need to use multivariate regression techniques to control for the individual characteristics. The next section presents the results of regressing the five employment outcomes on the variable Stayer and the individual characteristics.

\section{Empirical results}

\subsection{Differences between college town stayers and leavers}

Regression results for differences between college town stayers and leavers are presented in Table 4. The first column reports results for the probability of employment estimated via a linear probability model. The results are qualitatively robust to estimating probit and logit models. The estimated coefficient for Stayer is small and not statistically different from zero. In other words, the results suggest that there is no difference in the probability of employment for stayers and leavers. Recent college graduates from college towns have an equal probability of finding employment regardless of whether they stay in the area where they earned their degree or move to a different area. Note that this is in contrast to what was observed in Table 3, confirming the importance of using multivariate regression techniques to control for individual characteristics. Only a few of the additional variables have statistically significant effects on 
Table 3 Differences in means for stayers and leavers

\begin{tabular}{llll}
\hline Variable & Stayer Mean & Leaver Mean & Difference \\
\hline Employed & 0.911 & 0.925 & $-0.014^{* *}$ \\
Log Annual Wage & 9.874 & 10.164 & $-0.290^{* * *}$ \\
Log Hourly Wage & 2.458 & 2.660 & $-0.202^{* * *}$ \\
Log Annual Hours & 7.416 & 7.503 & $-0.087^{* * *}$ \\
\% of Occupation with Bachelor's or Higher & 0.481 & 0.544 & $-0.063^{* * *}$ \\
Master's Degree & 0.069 & 0.106 & $-0.037^{* * *}$ \\
Professional Degree & 0.026 & 0.034 & $-0.008^{* *}$ \\
Doctoral Degree & 0.003 & 0.004 & -0.002 \\
Age 24 & 0.175 & 0.177 & -0.002 \\
Age 25 & 0.214 & 0.241 & $-0.027^{* * *}$ \\
Age 26 & 0.222 & 0.251 & $-0.030^{* *}$ \\
Age 27 & 0.264 & 0.230 & $0.034^{* * *}$ \\
Female & 0.584 & 0.545 & $0.039^{* *}$ \\
Black & 0.058 & 0.038 & $0.019^{* * *}$ \\
Asian & 0.008 & 0.017 & $-0.009^{* * *}$ \\
Hispanic & 0.030 & 0.031 & -0.002 \\
Other Nonwhite & 0.013 & 0.013 & -0.001 \\
Married & 0.422 & 0.389 & $0.032^{*}$ \\
Has Children & 0.216 & 0.123 & $0.094^{* * *}$ \\
\hline No: Signicanta & &
\end{tabular}

Note: *Significant at $10 \%$; ${ }^{*}$ Significant at $5 \% ;{ }^{* *}$ Significant at $1 \%$.

the probability of employment for recent college graduates who lived in a college town five years prior. Persons who have earned a master's degree are significantly more likely to be employed than those who only have a bachelor's degree with an estimated coefficient of 0.019. Professional degrees and doctoral degrees, however, do not have a statistically significant effect on employment. Similarly, age does not have a significant effect on the probability of employment for recent graduates. Females are significantly less likely to be employed than males with a coefficient of -0.034 , but there are no significant differences based on race/ethnicity. Marriage has no significant effect on employment, but having children significantly reduces the probability of employment with a relatively large coefficient of -0.172 .

The second column of Table 4 reports results for the log of annual income from wages and salaries. First note that this regression and the following regressions have fewer observations than in the first column because some individuals did not work in the previous calendar year. Taking logs forces us to drop those with zero wages and hours because the log of zero is not defined. Turning to the results, Stayer has a statistically significant negative effect with a coefficient of -0.267 . This confirms that recent graduates who stay in the college town where they completed their degree on average accept much lower paying jobs than those who leave. Converting logs to percentages, the coefficient estimate suggests that college town stayers earn roughly 30 percent lower wages than those who leave. This is quite a price to pay for staying and helps explain why so many recent graduates leave college towns after completing their degrees. Several additional variables also have important effects on log annual wages. Interestingly, holders of professional degrees actually earn significantly lower annual 
Table 4 Regression results for employment outcomes

\begin{tabular}{|c|c|c|c|c|c|}
\hline & $\begin{array}{l}\text { Probability of } \\
\text { Employment }\end{array}$ & $\begin{array}{l}\text { Log } \\
\text { Annual } \\
\text { Wage }\end{array}$ & $\begin{array}{l}\text { Log } \\
\text { Hourly } \\
\text { Wage }\end{array}$ & $\begin{array}{l}\text { Log } \\
\text { Annual } \\
\text { Hours }\end{array}$ & $\begin{array}{l}\% \text { of Occupation with } \\
\text { Bachelor's or Higher }\end{array}$ \\
\hline \multirow[t]{2}{*}{ Stayer } & 0.001 & $-0.267^{* * *}$ & $-0.209^{* * *}$ & $-0.058^{* * *}$ & $-0.052^{* * *}$ \\
\hline & $(0.007)$ & $(0.020)$ & $(0.014)$ & $(0.015)$ & $(0.008)$ \\
\hline \multirow[t]{2}{*}{ Master's Degree } & $0.019^{* *}$ & -0.023 & $0.084^{* * *}$ & $-0.106^{* * *}$ & $0.157^{* * *}$ \\
\hline & $(0.008)$ & $(0.026)$ & $(0.020)$ & $(0.019)$ & $(0.009)$ \\
\hline \multirow[t]{2}{*}{ Professional Degree } & 0.011 & $-0.132^{* *}$ & 0.044 & $-0.176^{* * *}$ & $0.364^{* * *}$ \\
\hline & $(0.013)$ & $(0.053)$ & $(0.041)$ & $(0.041)$ & $(0.016)$ \\
\hline \multirow[t]{2}{*}{ Doctoral Degree } & 0.038 & 0.065 & $0.199^{*}$ & -0.134 & $0.258^{* * *}$ \\
\hline & $(0.029)$ & $(0.103)$ & $(0.104)$ & $(0.096)$ & $(0.048)$ \\
\hline \multirow[t]{2}{*}{ Age 24} & -0.003 & $0.190^{* * *}$ & 0.007 & $0.184^{* * *}$ & 0.002 \\
\hline & $(0.010)$ & $(0.032)$ & $(0.024)$ & $(0.026)$ & $(0.011)$ \\
\hline \multirow[t]{2}{*}{ Age 25} & -0.001 & $0.401^{* * *}$ & $0.108^{* * *}$ & $0.294^{* * *}$ & 0.015 \\
\hline & $(0.009)$ & $(0.031)$ & $(0.022)$ & $(0.025)$ & $(0.010)$ \\
\hline \multirow[t]{2}{*}{ Age 26} & 0.003 & $0.479^{* * *}$ & $0.155^{* * *}$ & $0.324^{* * *}$ & 0.002 \\
\hline & $(0.010)$ & $(0.031)$ & $(0.023)$ & $(0.025)$ & $(0.010)$ \\
\hline \multirow[t]{2}{*}{ Age 27} & 0.011 & $0.560^{* * *}$ & $0.175^{* * *}$ & $0.386^{* * *}$ & -0.007 \\
\hline & $(0.010)$ & $(0.031)$ & $(0.023)$ & $(0.025)$ & $(0.011)$ \\
\hline \multirow[t]{2}{*}{ Female } & $-0.034^{* * *}$ & $-0.208^{* * *}$ & $-0.115^{* * *}$ & $-0.092^{* * *}$ & $0.015^{* * *}$ \\
\hline & $(0.005)$ & $(0.015)$ & $(0.011)$ & $(0.011)$ & $(0.006)$ \\
\hline \multirow[t]{2}{*}{ Black } & -0.016 & $-0.082^{*}$ & -0.001 & $-0.082^{* *}$ & -0.022 \\
\hline & $(0.017)$ & $(0.042)$ & $(0.030)$ & $(0.033)$ & $(0.015)$ \\
\hline \multirow[t]{2}{*}{ Asian } & -0.008 & 0.120 & $0.158^{* *}$ & -0.038 & 0.028 \\
\hline & $(0.022)$ & $(0.073)$ & $(0.065)$ & $(0.057)$ & $(0.021)$ \\
\hline \multirow[t]{2}{*}{ Hispanic } & -0.019 & -0.012 & 0.052 & $-0.064^{*}$ & -0.004 \\
\hline & $(0.019)$ & $(0.043)$ & $(0.034)$ & $(0.036)$ & $(0.016)$ \\
\hline \multirow[t]{2}{*}{ Other Nonwhite } & -0.032 & -0.062 & 0.025 & $-0.087^{*}$ & $-0.065^{* * *}$ \\
\hline & $(0.023)$ & $(0.065)$ & $(0.054)$ & $(0.053)$ & $(0.024)$ \\
\hline \multirow[t]{2}{*}{ Married } & 0.006 & $0.080^{* * *}$ & $0.053^{* * *}$ & $0.027^{* *}$ & $0.030^{* * *}$ \\
\hline & $(0.005)$ & $(0.015)$ & $(0.012)$ & $(0.011)$ & $(0.006)$ \\
\hline \multirow[t]{2}{*}{ Has Children } & $-0.172^{* * *}$ & $-0.263^{* * *}$ & $-0.031^{*}$ & $-0.232^{* * *}$ & -0.015 \\
\hline & $(0.012)$ & $(0.030)$ & $(0.018)$ & $(0.025)$ & $(0.010)$ \\
\hline Observations & 11237 & 10700 & 10700 & 10700 & 10368 \\
\hline
\end{tabular}

Note: Heteroskedasticity robust standard errors in parentheses.

*Significant at $10 \%$; ${ }^{*}$ Significant at $5 \%$; ${ }^{* * *}$ Significant at $1 \%$.

wages than those with only a bachelor's degree with a coefficient of -0.132 . However, only 3.2 percent of the sample has a professional degree and they are likely to have earned that degree very recently and have very little work experience in their new job. Similarly, master's degrees and doctoral degrees do not significantly affect annual wages for this group. Age has a very strong effect on annual wages with older workers earning significantly more. Females earn significantly lower annual wages than males with a coefficient of -0.208 , and Blacks earn significantly lower annual wages than Whites with a coefficient of -0.082 . However, Asians, Hispanics and Other Nonwhites do not earn significantly different annual wages than Whites. Married persons earn 
significantly higher annual wages with a coefficient of 0.080 , and persons with children earn significantly lower annual wages with a coefficient of -0.263 .

Log annual wages can essentially be broken down into log hourly wages and log annual hours worked. The third and fourth columns of Table 4 report the results for these separate outcomes. According to the results, college town stayers both earn significantly lower hourly wages and work significantly fewer annual hours with coefficients of -0.209 and -0.058 , respectively. Notice that these two coefficients add up to the coefficient in the second column by definition. While both are significantly negative, the magnitude is much greater for log hourly wages and suggests that lower hourly wages account for 78 percent of the lower annual wages of stayers. The results for advanced education are again somewhat interesting. Master's degree holders have significantly higher hourly wages but significantly lower annual hours with coefficients of 0.084 and -0.106 . Professional degree holders earn similar hourly wages but work significantly fewer hours than persons with only a bachelor's degree with a coefficient of -0.176. For professional degrees the lower annual hours explains all of the lower annual wages in the second column. Given the age range considered, these results likely suggest that many master's and professional degree holders were in school for part of the previous year and devoted less time to work because of school. Doctoral degree holders earned significantly higher hourly wages with a coefficient of 0.199 , but the difference in hours worked is not statistically significant, probably due in part to the small number of doctorates in the sample. Age generally has a significantly positive effect on hourly wages and annual hours, except there is no difference in hourly wages between 23 and 24 year olds. Females earn lower hourly wages and work fewer annual hours with coefficients of -0.115 and -0.092 , respectively. Blacks earn similar hourly wages to Whites, but work significantly fewer hours with a coefficient of -0.082 . Asians earn higher hourly wages with a coefficient of 0.158 but do not work significantly different hours than Whites. Hispanics and Other Nonwhites earn similar wages to Whites but work significantly fewer hours with coefficients of -0.064 and -0.087 , respectively. Married persons earn significantly higher hourly wages and work significantly more hours with coefficients of 0.053 and 0.027 . Those with children earn significantly lower hourly wages and work significantly fewer hours with coefficients of -0.031 and -0.232 .

The fifth column of Table 4 reports the results of regressing the share of workers in a worker's 3-digit occupation with a bachelor's degree or higher on the individual characteristics. The sample for this regression only includes recent graduates who are currently employed, which results in fewer observations than in the previous columns. The dependent variable is computed based on all workers in the U.S. between the ages of 23 and 39 regardless of where they work or where they resided five years prior. This variable is meant to measure the extent to which an occupation requires a four-year college degree. Some recent college graduates are likely to end up taking jobs where a college degree is not essential for the job. This may be especially true for recent graduates who stay in a small college town after finishing their degree. The results in the fifth column suggest that this is indeed the case. The variable Stayer has a negative and significant effect with a coefficient of -0.052 . College town stayers, therefore, on average work in less educated occupations than college town leavers. Not surprisingly, the results also suggest that workers with advanced degrees end up working in more educated occupations with statistically significant coefficients of $0.157,0.364$, and 0.258 for 
workers with a master's, professional, and doctoral degree. Age has a statistically insignificant effect on the occupational education measure. Females work in significantly more educated occupations than males with a coefficient of 0.015. Blacks, Asians, and Hispanics work in occupations with similar education levels as Whites, but Other Nonwhites work in significantly less educated occupation with a coefficient of -0.065 . Married individuals work in significantly more educated occupations with a coefficient of 0.030 , but persons with children do not work in occupations with significantly different education levels than persons without children.

\subsection{Difference in differences approach with recent graduates from large metro areas}

The results thus far suggest that recent college graduates who stay in the college town where they completed their degree experience significantly worse employment outcomes than those who leave college towns. Furthermore, the magnitudes of these effects are often quite large. The difference in annual wages between stayers and leavers is roughly 30 percent, a very large effect. A major concern, however, is that stayers and leavers are self-selected groups and might differ along unobserved dimensions. For example, leavers might have more drive and ambition that also makes them more productive workers. Unfortunately, the census microdata do not provide much information that would be useful in examining the endogeneity of migration. However, we can offer some additional insight about the effects on recent graduates of staying in a college town by employing a difference in differences (DD) regression technique that treats recent graduates from large metropolitan areas as a control group.

The DD approach for each employment outcome variable, Y, involves estimating the following regression for recent graduates who either resided in a college town or a large metropolitan area five years prior to the Census:

$$
Y=\gamma \times \text { Stayer }+\delta \times \text { CollegeTown }+\theta \times \text { Stayer } \times \text { CollegeTown }+X \beta+\varepsilon
$$

where Stayer is an indicator variable equal to one if a recent graduate still resides in the same area as they did five years prior and zero otherwise, and CollegeTown is an indicator variable equal to one if a recent graduate resided in a college town five years prior and equal to zero if the recent graduate was in a large metro area five years prior. For the results presented, we define large metropolitan areas as those with a year 2000 population of at least 5,000,000, but the results are qualitatively robust to defining large metros as all those with at least 1,000,000 people. The DD regressions also include a variable for the interaction of Stayer and CollegeTown, which measures the difference in stayer-leaver differences between college towns and large metro areas. This interaction term is now the primary variable of interest. The DD procedure is an attempt to account for selection on unobservables by assuming that recent graduates select into migration in similar ways in college towns and large metro areas. If this assumption is violated, the DD procedure may also lead to invalid estimates.

Before proceeding to the DD results, it is first informative to simply compare raw differences in means between recent graduate stayers and leavers from large metropolitan areas. These comparisons are reported in Table 5. As seen, the raw differences between stayers and leavers from large metros are small and insignificant for employment probabilities, annual wages, and occupational education levels. Large metro stayers do earn significantly higher hourly wages but work significantly fewer annual hours. 
Table 5 Differences in means for large metro area stayers and leavers

\begin{tabular}{|c|c|c|c|}
\hline Variable & Stayer Mean & Leaver Mean & Difference \\
\hline Employed & 0.913 & 0.915 & -0.001 \\
\hline Log Annual Wage & 10.162 & 10.145 & 0.017 \\
\hline Log Hourly Wage & 2.722 & 2.669 & $0.053^{* * *}$ \\
\hline Log Annual Hours & 7.440 & 7.476 & $-0.036^{* * *}$ \\
\hline$\%$ of Occupation with Bachelor's or Higher & 0.529 & 0.528 & 0.001 \\
\hline Master's Degree & 0.090 & 0.110 & $-0.020^{* * *}$ \\
\hline Professional Degree & 0.030 & 0.046 & $-0.015^{* * *}$ \\
\hline Doctoral Degree & 0.004 & 0.005 & $-0.002^{* *}$ \\
\hline Age 24 & 0.182 & 0.183 & -0.001 \\
\hline Age 25 & 0.196 & 0.198 & -0.002 \\
\hline Age 26 & 0.210 & 0.221 & $-0.011^{*}$ \\
\hline Age 27 & 0.246 & 0.242 & 0.005 \\
\hline Female & 0.566 & 0.546 & $0.020^{* * *}$ \\
\hline Black & 0.077 & 0.052 & $0.025^{* * *}$ \\
\hline Asian & 0.049 & 0.045 & 0.003 \\
\hline Hispanic & 0.069 & 0.042 & $0.027^{* * *}$ \\
\hline Other Nonwhite & 0.017 & 0.026 & $-0.009^{* * *}$ \\
\hline Married & 0.229 & 0.264 & $-0.035^{* * *}$ \\
\hline Has Children & 0.089 & 0.083 & $0.006^{*}$ \\
\hline
\end{tabular}

Notes: The sample includes 37,475 recent college graduates (27,661 Stayers and 9814 Leavers) who resided in one of 10 large metropolitan areas in 1995. Large metropolitan areas are defined as metro areas with a year 2000 total population of $5,000,000$ or greater.

*Significant at $10 \%$; * Significant at $5 \%$; ${ }^{* *}$ Significant at $1 \%$.

Importantly, there are also some significant differences in individual characteristics. Also, though not explicitly shown, there is a considerable difference between college towns and large metro areas in the percentage of recent graduates who stay in the area after completing their degree. While only 19.4 percent of recent graduates from college towns are classified as stayers, 73.8 percent of recent graduates from large metros are considered stayers.

The DD regression results for the five employment outcomes are reported in Table 6 . For the employment regression in the first column, Stayer has a small and insignificant coefficient, while CollegeTown has a significantly positive coefficient of 0.013 . The interaction of Stayer and CollegeTown has a small and insignificant coefficient, reaffirming the results in Table 4 that staying in a college town after graduating does not affect the probability of employment. The results for log annual wages are presented in the second column of Table 6; Stayer has a statistically significant coefficient of 0.024, suggesting that recent graduates who stay in the large metropolitan area where they completed their degree actually earn slightly higher annual wages than recent graduates from large metros who leave. CollegeTown has a significant coefficient of -0.024 , suggesting that college town leavers on average earn slightly lower annual wages than big city leavers. Again, the interaction of Stayer and CollegeTown is the main explanatory variable of interest and has a significant negative effect on $\log$ wages with a coefficient of -0.292 . This reaffirms that staying in a college town results in significantly lower annual wages for recent graduates even when we treat recent graduates from large metro areas as a control group. 
Table 6 DD regression results for recent graduates from college towns and large metros

\begin{tabular}{|c|c|c|c|c|c|}
\hline & $\begin{array}{l}\text { Probability of } \\
\text { Employment }\end{array}$ & $\begin{array}{l}\text { Log } \\
\text { Annual } \\
\text { Wage }\end{array}$ & $\begin{array}{l}\text { Log } \\
\text { Hourly } \\
\text { Wage }\end{array}$ & $\begin{array}{l}\text { Log } \\
\text { Annual } \\
\text { Hours }\end{array}$ & $\begin{array}{l}\% \text { of Occupation with } \\
\text { Bachelor's or Higher }\end{array}$ \\
\hline \multirow[t]{2}{*}{ Stayer } & 0.000 & $0.024^{* *}$ & $0.063^{* * *}$ & $-0.039^{* * *}$ & $0.014^{* * *}$ \\
\hline & $(0.004)$ & $(0.010)$ & $(0.008)$ & $(0.008)$ & $(0.003)$ \\
\hline \multirow[t]{2}{*}{ CollegeTown } & $0.013^{* * *}$ & $-0.024^{*}$ & $-0.020^{* *}$ & -0.004 & $0.015^{* * *}$ \\
\hline & $(0.004)$ & $(0.012)$ & $(0.009)$ & $(0.009)$ & $(0.004)$ \\
\hline \multirow[t]{2}{*}{ Stayer*CollegeTown } & -0.002 & $-0.292^{* * *}$ & $-0.270^{* * *}$ & -0.022 & $-0.068^{* * *}$ \\
\hline & $(0.008)$ & $(0.023)$ & $(0.016)$ & $(0.017)$ & $(0.008)$ \\
\hline \multirow[t]{2}{*}{ Master's Degree } & 0.005 & -0.020 & $0.074^{* * *}$ & $-0.094^{* * *}$ & $0.156^{* * *}$ \\
\hline & $(0.004)$ & $(0.013)$ & $(0.010)$ & $(0.010)$ & $(0.004)$ \\
\hline \multirow[t]{2}{*}{ Professional Degree } & -0.010 & $-0.042^{*}$ & $0.106^{* * *}$ & $-0.148^{* * *}$ & $0.300^{* * *}$ \\
\hline & $(0.008)$ & $(0.023)$ & $(0.020)$ & $(0.019)$ & $(0.009)$ \\
\hline \multirow[t]{2}{*}{ Doctoral Degree } & $-0.070^{* * *}$ & -0.069 & 0.084 & $-0.152^{* * *}$ & $0.277^{* * *}$ \\
\hline & $(0.026)$ & $(0.069)$ & $(0.064)$ & $(0.055)$ & $(0.023)$ \\
\hline \multirow[t]{2}{*}{ Age 24} & 0.002 & $0.267^{* * *}$ & $0.052^{* * *}$ & $0.215^{* * *}$ & -0.002 \\
\hline & $(0.005)$ & $(0.015)$ & $(0.011)$ & $(0.011)$ & $(0.005)$ \\
\hline \multirow[t]{2}{*}{ Age 25} & 0.005 & $0.476^{* * *}$ & $0.170^{* * *}$ & $0.307^{* * *}$ & $0.010^{* *}$ \\
\hline & $(0.005)$ & $(0.014)$ & $(0.010)$ & $(0.011)$ & $(0.005)$ \\
\hline \multirow[t]{2}{*}{ Age 26} & 0.007 & $0.572^{* * *}$ & $0.221^{* * *}$ & $0.351^{* * *}$ & 0.002 \\
\hline & $(0.005)$ & $(0.014)$ & $(0.010)$ & $(0.011)$ & $(0.005)$ \\
\hline \multirow[t]{2}{*}{ Age 27} & $0.019^{* * *}$ & $0.660^{* * *}$ & $0.268^{* * *}$ & $0.392^{* * *}$ & -0.002 \\
\hline & $(0.005)$ & $(0.014)$ & $(0.010)$ & $(0.011)$ & $(0.005)$ \\
\hline \multirow[t]{2}{*}{ Female } & $-0.015^{* * *}$ & $-0.163^{* * *}$ & $-0.082^{* * *}$ & $-0.081^{* * *}$ & $0.026^{* * *}$ \\
\hline & $(0.003)$ & $(0.008)$ & $(0.006)$ & $(0.006)$ & $(0.003)$ \\
\hline \multirow[t]{2}{*}{ Black } & $-0.042^{* * *}$ & $-0.084^{* * *}$ & $-0.035^{* * *}$ & $-0.049^{* * *}$ & $-0.027^{* * *}$ \\
\hline & $(0.007)$ & $(0.017)$ & $(0.013)$ & $(0.013)$ & $(0.006)$ \\
\hline \multirow[t]{2}{*}{ Asian } & $-0.041^{* * *}$ & $0.093^{* * *}$ & $0.156^{* * *}$ & $-0.063^{* * *}$ & $0.025^{* * *}$ \\
\hline & $(0.008)$ & $(0.022)$ & $(0.017)$ & $(0.018)$ & $(0.007)$ \\
\hline \multirow[t]{2}{*}{ Hispanic } & $-0.026^{* * *}$ & $-0.074^{* * *}$ & $-0.047^{* * *}$ & $-0.027^{* *}$ & $-0.014^{* *}$ \\
\hline & $(0.007)$ & $(0.017)$ & $(0.013)$ & $(0.013)$ & $(0.006)$ \\
\hline \multirow[t]{2}{*}{ Other Nonwhite } & $-0.028^{* *}$ & $-0.113^{* * *}$ & $-0.063^{* * *}$ & $-0.050^{* *}$ & $-0.032^{* * *}$ \\
\hline & $(0.011)$ & $(0.031)$ & $(0.022)$ & $(0.021)$ & $(0.010)$ \\
\hline \multirow[t]{2}{*}{ Married } & $0.008^{* * *}$ & $0.107^{* * *}$ & $0.065^{* * *}$ & $0.042^{* * *}$ & $0.035^{* * *}$ \\
\hline & $(0.003)$ & $(0.008)$ & $(0.007)$ & $(0.006)$ & $(0.003)$ \\
\hline \multirow[t]{2}{*}{ Has Children } & $-0.151^{* * *}$ & $-0.252^{* * *}$ & $-0.047^{* * *}$ & $-0.205^{* * *}$ & $-0.028^{* * *}$ \\
\hline & $(0.007)$ & $(0.017)$ & $(0.011)$ & $(0.013)$ & $(0.006)$ \\
\hline Observations & 48712 & 46101 & 46101 & 46101 & 44614 \\
\hline
\end{tabular}

Note: Heteroskedasticity robust standard errors in parentheses.

*Significant at $10 \%$; ${ }^{*}$ Significant at $5 \%$; ${ }^{* *}$ Significant at $1 \%$.

The third and fourth columns of Table 6 report the results for log hourly wages and $\log$ annual hours, respectively. Stayer has a significantly positive effect on log hourly wages but a significantly negative effect on $\log$ annual hours with coefficients of 0.063 and -0.039 , respectively. Thus, large metro stayers earn higher hourly wages but work fewer hours than large metro leavers. CollegeTown has a significantly negative 
coefficient for log hourly wages of -0.020 but an insignificant effect on log annual hours. The interaction term has a significantly negative effect on hourly wages with a coefficient of -0.270 but an insignificant effect on log annual hours. These results suggest that nearly all of the adverse effect of staying in a college town on annual wages results from lower hourly wages.

The fifth column of Table 6 presents results for the percent of workers in an occupation with a bachelor's degree or higher. Stayer has a significantly positive effect with a coefficient of 0.014 suggesting that large metro stayers work in slightly more educated occupations than large metro leavers. CollegeTown also has a significantly positive coefficient of 0.015 , suggesting that college town leavers also work in slightly more educated occupations than large metro stayers. The interaction term is negative and significant with a coefficient of -0.068 , reaffirming that staying in a college town increases the likelihood of recent graduates taking jobs in occupations that do not require a four-year college degree.

\subsection{Difference in differences approach controlling for the cost of living}

The DD results in the previous sub-section show that staying in a college town worsens employment outcomes for recent graduates along multiple dimensions, even when we use recent graduates from large metropolitan areas as a control group. However, a legitimate concern is that the effects on individual well-being might be overstated by the effects on nominal wages if college towns have lower costs of living than the destination areas of college town leavers. In other words, it might not make sense to compare the nominal wages of college town stayers to the nominal wages of college town leavers, large metro stayers, and large metro leavers if these latter groups live in more expensive areas. Assessing individual well-being requires comparing "real wages", that is wages adjusted for the local cost of living. Therefore, we next re-estimate the DD regressions in Table 6 while adding a control for the cost of living. We control for the cost of living by adding to the regressions a measure of average logarithmic differences in housing rental payments for each individual's current location computed using microdata from the 2000 Census. This measure, referred to as Mean log rent, is computed by regressing the log of gross rents, $R$, for each rental housing unit $i$ in area $j$ on a vector of housing characteristics, $H$, and a vector of area fixed-effects ${ }^{5}, \pi$ :

$$
\ln R_{i j}=H_{i j} \Gamma+\pi_{j}+u_{i j}
$$

The housing characteristics included are dummy variables for the number of bedrooms, the total number of rooms, the age of the structure, the number of units in the building, modern plumbing, modern kitchen facilities, and lot size for single-family homes. The results for this regression are available upon request. The area fixed-effects from (3) measure quality-adjusted average logarithmic differences in rents across areas and are used to control for differences in the cost of living across areas. One also could use housing values instead of rents to measure cost of living differences across areas, but Winters (2009) suggests that rents are a more appropriate measure of the cost of living.

Table 7 presents the results of adding Mean log rent to the DD regressions to control for the cost of living in the current location. As seen in the first column of Table 7, Mean $\log$ rent has a significant effect on the probability of employment with a 
Table 7 DD regression results controlling for the cost of living

\begin{tabular}{|c|c|c|c|c|c|}
\hline & $\begin{array}{l}\text { Probability of } \\
\text { Employment }\end{array}$ & $\begin{array}{l}\text { Log } \\
\text { Annual } \\
\text { Wage }\end{array}$ & $\begin{array}{l}\text { Log } \\
\text { Hourly } \\
\text { Wage } \\
\end{array}$ & $\begin{array}{l}\text { Log } \\
\text { Annual } \\
\text { Hours }\end{array}$ & $\begin{array}{l}\% \text { of Occupation with } \\
\text { Bachelor's or Higher }\end{array}$ \\
\hline \multirow[t]{2}{*}{ Stayer } & 0.003 & $-0.018^{*}$ & $0.018^{* *}$ & $-0.036^{* * *}$ & $0.014^{* * *}$ \\
\hline & $(0.004)$ & $(0.011)$ & $(0.008)$ & $(0.008)$ & $(0.004)$ \\
\hline \multirow[t]{2}{*}{ CollegeTown } & $0.011^{* * *}$ & 0.007 & 0.013 & -0.006 & $0.015^{* * *}$ \\
\hline & $(0.004)$ & $(0.012)$ & $(0.009)$ & $(0.009)$ & $(0.004)$ \\
\hline \multirow[t]{2}{*}{ Stayer*CollegeTown } & -0.007 & $-0.203^{* * *}$ & $-0.175^{* * *}$ & -0.028 & $-0.067^{* * *}$ \\
\hline & $(0.008)$ & $(0.023)$ & $(0.016)$ & $(0.017)$ & $(0.009)$ \\
\hline Mean Log Rent & $-0.025^{* * *}$ & $0.389^{* * *}$ & $0.416^{* * *}$ & -0.027 & 0.003 \\
\hline (Current Location) & $(0.008)$ & $(0.023)$ & $(0.017)$ & $(0.017)$ & $(0.008)$ \\
\hline \multirow[t]{2}{*}{ Master's Degree } & 0.005 & $-0.024^{*}$ & $0.070^{* * *}$ & $-0.094^{* * *}$ & $0.156^{* * *}$ \\
\hline & $(0.004)$ & $(0.013)$ & $(0.010)$ & $(0.010)$ & $(0.004)$ \\
\hline \multirow[t]{2}{*}{ Professional Degree } & -0.010 & $-0.044^{*}$ & $0.103^{* * *}$ & $-0.147^{* * *}$ & $0.300^{* * *}$ \\
\hline & $(0.008)$ & $(0.023)$ & $(0.020)$ & $(0.019)$ & $(0.009)$ \\
\hline \multirow[t]{2}{*}{ Doctoral Degree } & $-0.070^{* * *}$ & -0.061 & 0.092 & $-0.153^{* * *}$ & $0.277^{* * *}$ \\
\hline & $(0.026)$ & $(0.070)$ & $(0.065)$ & $(0.055)$ & $(0.023)$ \\
\hline \multirow[t]{2}{*}{ Age 24} & 0.002 & $0.265^{* * *}$ & $0.051^{* * *}$ & $0.215^{* * *}$ & -0.002 \\
\hline & $(0.005)$ & $(0.015)$ & $(0.011)$ & $(0.011)$ & $(0.005)$ \\
\hline \multirow[t]{2}{*}{ Age 25} & 0.005 & $0.472^{* * *}$ & $0.165^{* * *}$ & $0.307^{* * *}$ & $0.010^{* *}$ \\
\hline & $(0.005)$ & $(0.014)$ & $(0.010)$ & $(0.011)$ & $(0.005)$ \\
\hline \multirow[t]{2}{*}{ Age 26} & 0.007 & $0.567^{* * *}$ & $0.215^{* * *}$ & $0.352^{* * *}$ & 0.002 \\
\hline & $(0.005)$ & $(0.014)$ & $(0.010)$ & $(0.011)$ & $(0.005)$ \\
\hline \multirow[t]{2}{*}{ Age 27} & $0.019^{* * *}$ & $0.653^{* * *}$ & $0.261^{* * *}$ & $0.393^{* * *}$ & -0.002 \\
\hline & $(0.005)$ & $(0.014)$ & $(0.010)$ & $(0.011)$ & $(0.005)$ \\
\hline \multirow[t]{2}{*}{ Female } & $-0.015^{* * *}$ & $-0.164^{* * *}$ & $-0.083^{* * *}$ & $-0.081^{* * *}$ & $0.026^{* * *}$ \\
\hline & $(0.003)$ & $(0.008)$ & $(0.006)$ & $(0.006)$ & $(0.003)$ \\
\hline \multirow[t]{2}{*}{ Black } & $-0.042^{* * *}$ & $-0.081^{* * *}$ & $-0.032^{* *}$ & $-0.049^{* * *}$ & $-0.027^{* * *}$ \\
\hline & $(0.007)$ & $(0.017)$ & $(0.013)$ & $(0.013)$ & $(0.006)$ \\
\hline \multirow[t]{2}{*}{ Asian } & $-0.038^{* * *}$ & $0.053^{* *}$ & $0.113^{* * *}$ & $-0.060^{* * *}$ & $0.024^{* * *}$ \\
\hline & $(0.008)$ & $(0.022)$ & $(0.017)$ & $(0.018)$ & $(0.007)$ \\
\hline \multirow[t]{2}{*}{ Hispanic } & $-0.024^{* * *}$ & $-0.095^{* * *}$ & $-0.070^{* * *}$ & $-0.026^{* *}$ & $-0.014^{* *}$ \\
\hline & $(0.007)$ & $(0.017)$ & $(0.013)$ & $(0.013)$ & $(0.006)$ \\
\hline \multirow[t]{2}{*}{ Other Nonwhite } & $-0.026^{* *}$ & $-0.135^{* * *}$ & $-0.086^{* * *}$ & $-0.048^{* *}$ & $-0.032^{* * *}$ \\
\hline & $(0.011)$ & $(0.031)$ & $(0.022)$ & $(0.021)$ & $(0.011)$ \\
\hline \multirow[t]{2}{*}{ Married } & $0.006^{* *}$ & $0.126^{* * *}$ & $0.085^{* * *}$ & $0.040^{* * *}$ & $0.035^{* * *}$ \\
\hline & $(0.003)$ & $(0.008)$ & $(0.007)$ & $(0.006)$ & $(0.003)$ \\
\hline \multirow[t]{2}{*}{ Has Children } & $-0.151^{* * *}$ & $-0.240^{* * *}$ & $-0.035^{* * *}$ & $-0.206^{* * *}$ & $-0.028^{* * *}$ \\
\hline & $(0.007)$ & $(0.017)$ & $(0.011)$ & $(0.013)$ & $(0.006)$ \\
\hline Observations & 48712 & 46101 & 46101 & 46101 & 44614 \\
\hline
\end{tabular}

Note: Heteroskedasticity robust standard errors in parentheses. ${ }^{*}$ Significant at $10 \%$; ${ }^{*}$ Significant at $5 \%$; ***Significant at $1 \%$. 
coefficient of -0.025 , but controlling for the cost of living does not meaningfully affect the main results for the probability of employment. CollegeTown is again significant with a coefficient of 0.011 , but Stayer and the interaction term are again statistically insignificant. The result for the interaction term again suggests that staying in a college town after graduating does not affect the probability of employment.

The results of controlling for the cost of living in the log annual wage DD regression are reported in the second column of Table 7. As expected, Mean log rent has a significantly positive effect on log annual wages with a coefficient of 0.389 . This result suggests that a one percent increase in housing rents results in a roughly 0.4 percent increase in annual wages to compensate workers for the higher cost of living. Controlling for the cost of living also changes the effect of Stayer on log annual wages. Stayer had a significantly positive effect on log annual wages in Table 6, but after controlling for the cost of living the effect is significantly negative with a coefficient of -0.018 . This suggests that large metro stayers earn slightly lower annual wages than large metro leavers after controlling for the higher cost of living in large metro areas. Controlling for the cost of living, prior residence in a college town has a small and insignificant effect on annual wages. The interaction of Stayer and CollegeTown again has a significantly negative effect on log annual wages, but the coefficient of -0.203 is somewhat smaller than the corresponding estimate in Table 6. The implication is that after controlling for the cost of living, staying in a college town reduces annual wages for recent graduates by roughly 22.5 percent.

The third and fourth columns of Table 7 present the DD results for log hourly wages and $\log$ annual hours worked controlling for the cost of living. Mean log rent has a significantly positive effect on log hourly wages with a coefficient of 0.416 but an insignificant effect on log annual hours, suggesting that for recent graduates the cost of living affects hourly wages but not hours worked. Stayer again has a significantly positive effect on log hourly wages and a significantly negative effect on $\log$ annual hours with coefficients of 0.018 and -0.036 , respectively. CollegeTown now has an insignificant effect on both log hourly wages and log annual hours. The interaction of Stayer and CollegeTown has a statistically negative effect on log hourly wages with a coefficient of -0.175 and an insignificant effect on log annual hours.

The fifth column of Table 7 presents the results for the percent of workers in an occupation with a bachelor's degree or higher controlling for the cost of living. As seen, Mean $\log$ rent has a statistically insignificant effect on the occupational education measure and controlling for the cost of living has no meaningful effect on the main results in the fifth column. Stayer and CollegeTown again have significantly positive effects with coefficients of 0.014 and 0.015 , respectively. The interaction of the two again has a significantly negative effect with a coefficient of -0.067 , suggesting that staying in a college town forces recent graduates to accept jobs in less educated occupations.

\section{Conclusion}

Individuals choose to live and work in the location that gives them the highest possible utility. Many recent college graduates prefer to stay in the area where they completed their degree because they have developed location-specific human capital that increases 
the area's desirability. However, staying in the area where one attended college may worsen employment prospects, especially for persons attending college in relatively small college towns. Using decennial census microdata for the U.S., this paper finds that recent graduates who stay in the college towns where they earned their degrees pay a considerable price for doing so. They earn lower annual and hourly wages and accept jobs in less educated occupations. Furthermore, the magnitudes of these effects are often quite large. The nominal difference in annual wages between college town stayers and leavers is roughly 30 percent. Even after controlling for the cost of living and treating recent graduates from large metro areas as a control group in an attempt to account for selection effects, staying in a college town still reduces annual wages by roughly 22.5 percent. Some recent graduates stay in the area because of local attachments that they have developed, but doing so often requires them to take lower paying jobs than they could find elsewhere.

\section{Endnotes}

${ }^{1}$ Researchers have suggested that society further benefits because college educated workers increase productivity, wages, and employment prospects for other workers (Rauch 1993; Moretti 2004, Winters 2012). The external benefits of human capital also attract additional workers and cause highly educated metropolitan areas in the U.S. to experience greater in-migration and population growth (Glaeser, Scheinkman and Shleifer 1995; Simon and Nardinelli 2002; Winters 2011).

${ }^{2}$ An additional caveat is that advanced education, marital status and having children may be simultaneously determined with employment outcomes. However, removing these variables from the analysis does not change the qualitative results presented below.

${ }^{3}$ Even if this information were available, it would be unlikely to fully alleviate endogeneity concerns since few young college students are homeowners and proximity to family while in college may itself be correlated with unobserved characteristics that affect employment prospects.

${ }^{4}$ An additional issue suggested by previous literature is that employment differences between movers and stayers may be affected by the amount of time since the move. Unfortunately, we do not know exactly when people move and are unable to offer evidence on how the effects evolve over time.

${ }^{5}$ Gross rents are measured to include certain utilities payments. For these purposes, areas are defined as metropolitan areas where they exist and state non-metropolitan areas for areas not part of a metro area.

Competing interests

The IZA Journal of Migration is committed to the IZA Guiding Principles of Research Integrity. The author declares that he has observed these principles.

\section{Acknowledgements}

The author thanks anonymous referees and Editor Amelie Constant for helpful comments.

Responsible editor: Amelie Constant

Received: 5 July 2012 Accepted: 5 December 2012

Published: 28 December 2012

References

Anil B, Sjoquist DL, Wallace S (2010) The effect of a program-based housing move on employment: HOPE VI in Atlanta. South Econ J 77:138-160 
Axelsson R, Westerlund O (1998) A panel study of migration, self-selection and household real income. J Popul Econ 11:113-126

Berry CR, Glaeser EL (2005) The divergence of human capital levels across cities. Pap Reg Sci 84:407-444

Blackburn ML (2010a) The impact of internal migration on married couples' earnings in Britain. Economica 77:584-603

Blackburn ML (2010b) Internal migration and the earnings of married couples in the United States. J Econ Geogr 10:87-111

Böheim R, Taylor MP (2002) From the dark end of the street to the bright side of the road? the wage returns to migration in Britain. Labour Econ 14:99-117

Chen Y, Rosenthal SS (2008) Local amenities and life-cycle migration: do people move for jobs or fun? I Urban Econ 64:519-537

Clark DE, Hunter WJ (1992) the impact of economic opportunity, amenities, and fiscal factors on age-specific migration. $J$ Reg Sci 32:349-365

DaVanzo J (1983) Repeat migration in the United States: who moves back and who moves on? Rev Econ Stat 65:552-559 Franklin RS (2003) Migration of the young, single and college educated: 1995 to 2000 Census 2000 special reports, CENSR-12 Washington. US Government Printing Office, DC

Glaeser EL, Scheinkman JA, Shleifer A (1995) Economic growth in a cross-section of cities. J Monet Econ 36:117-143

Groen JA (2004) The effect of college location on migration of college-educated labor. J Econom 121:125-142

Huffman D, Quigley JM (2002) The role of the university in attracting high tech entrepreneurship: a Silicon Valley tale. Ann Reg Sci 36:403-419

Krupka DJ (2009) Location-specific human capital, location choice and amenity demand. J Reg Sci 49:833-854

Moretti E (2004) Estimating the social return to higher education: evidence from longitudinal and repeated crosssectional data. J Econom 121:175-212

Oosterbeek H, Webbink D (2011) Does studying abroad induce a brain drain? Economica 78:347-366

Psacharopoulos G, Patrinos HA (2004) Returns to investment in education: a further update. Educ Econ 12:111-134

Rauch JE (1993) Productivity gains from geographic concentration of human capital: evidence from the cities. J Urban Econ 34:380-400

Ruggles S, Sobek M, Alexander T, Fitch CA, Goeken R, Hall PK, King M, Ronnander C (2008) Integrated Public Use Microdata Series. Version 4.0. Minneapolis, Minnesota Population Center

Simon CJ, Nardinelli C (2002) Human capital and the rise of American cities, 1900-1990. Reg Sci Urban Econ 32:59-96

Sjaastad LA (1962) The costs and returns of human migration. J Polit Econ 70:80-93

Waldorf BS (2009) Is human capital accumulation a self-propelling process? comparing educational attainment levels of movers and stayers. Ann Reg Sci 43:323-344

Whisler RL, Waldorf BS, Mulligan GF, Plane DA (2008) Quality of life and the migration of the college-educated: a lifecourse approach. Growth Chang 39:58-94

Winters JV (2009) Wages and prices: are workers fully compensated for cost of living differences? Reg Sci Urban Econ 39:632-643

Winters JV (2011) Why are smart cities growing? who moves and who stays. J Reg Sci 51:253-270

Winters JV (2012) Human capital externalities and employment differences across metropolitan areas of the US. J Econ Geogr Forthcoming

Yankow JJ (2003) Migration, job change, and wage growth: a new perspective on the pecuniary return to geographic mobility. J Reg Sci 43:483-516

doi:10.1186/2193-9039-1-11

Cite this article as: Winters: Differences in employment outcomes for college town stayers and leavers. IZA

Journal of Migration 2012 1:11.

\section{Submit your manuscript to a SpringerOpen ${ }^{\circ}$ journal and benefit from:}

- Convenient online submission

- Rigorous peer review

- Immediate publication on acceptance

- Open access: articles freely available online

- High visibility within the field

- Retaining the copyright to your article

Submit your next manuscript at $\boldsymbol{\nabla}$ springeropen.com 